\title{
ANNOUNCEMENTS
}

\section{THE SESQUICENTENNIAL OF THE FIRST EDITION OF LEAVES OF GRASS}

2005 is the sesquicentennial of the first edition of Leaves of Grass. A number of conferences and special events have been planned to celebrate the $150^{\text {th }}$ anniversary of one of America's greatest and most original books. Listed below is information on the events that have already been scheduled. Additional events will be listed in the next issue of the Walt Whitman Quarterly Revierw, and an events calendar will be continually updated on the WWQR website (www.uiowa.edu/ wwqr) in the "Announcements" section.

"Leaves of Grass: The $150^{\text {th }}$ Anniversary Conference" will be held from March 31 to April 2, 2005, at the University of Nebraska in Lincoln. Directed by Susan Belasco, Ed Folsom, and Kenneth M. Price, this conference will bring together some of the most distinguished American literature scholars from around the world, including Lawrence Buell (Harvard University), Matt Cohen (Duke University), Betsy Erkkila (Northwestern University), Ed Folsom (University of Iowa), Tom Gannon (University of Nebraska-Lincoln), Ted Genoways (University of Virginia), Ezra Greenspan (Southern Methodist University), Jay Grossman (Northwestern University), Walter Grünzweig (University of Dortmund), M. Jimmie Killingsworth (Texas A\&M University), Donald D. Kummings (University of Wisconsin-Parkside), Jerome Loving (Texas A\&M University), Joel Myerson (University of South Carolina), William Pannapacker (Hope College), Kenneth M. Price (University of Nebraska-Lincoln), Vivian Pollak (Washington University), David S. Reynolds (City University of New York, Graduate Center), Liu Shusen (Peking University), M. Wynn Thomas (University of Wales, Swansea), and Alan Trachtenberg (Yale University). Poets Galway Kinnell and Ted Kooser will give readings. Renowned jazz pianist Fred Hersch will perform his own composition "Leaves of Grass," and the University of Nebraska Symphony Orchestra will perform Paul Hindemith's "When Lilacs Last in the Dooryard Bloom'd (Requiem for Those We Love)" and will give the world premiere of Tyler White's "Mystic Trumpeter." A number of Whitman collectors will be present to discuss their collections and exhibit Whitman materials. Essays from the conference will be published in a collection to be issued by the University of Nebraska Press. Registration information, schedules, and other details are available on the Web at www.unl.edu/ leavesofgrass/index.html.

The Walt Whitman Birthplace Association is conducting a "Leaves of Grass $150^{\text {th }}$ Anniversary Festival," with a number of events scheduled from April through June of 2005 at the birthplace (246 Old Walt Whitman Road, West Hills, NY 11746-4148). Included will be a Walt Whitman Heritage Lecture on 
May 22 at 1:30 p.m. by Joann P. Krieg, whose talk on "Celebrating the Leaves" will examine the 1855 edition and its contexts; the Walt Whitman Birthday Celebration at noon on June 5, with Nikki Giovanni, the Walt Whitman Birthplace Association 2005 Poet-in-Residence, reading her own and Whitman's works, along with the Sampawams Creek musicians playing music of the period, and the announcement of the winners of Long Island's Best Young Poets Contest Grades 3-12; chamber music and readings of Walt Whitman to commemorate the $150^{\text {th }}$ anniversary, featuring Gary Soto, Walt Whitman Birthplace Association 2002 Poet-in-Residence, and Daniel Thomas Moran, presented by the Chamber Players International and the Birthplace Association, at Hoffman Center, Old Brookville, June 11 from 3:00 to 6:00 p.m.; and, on June 18 at 2:00 p.m., the Leaves of Grass 150 th Anniversary Celebration, featuring Billy Collins, New York State Poet Laureate, former U.S. Poet Laureate, and Walt Whitman Birthplace Association 2001 Poet-in-Residence, Walt Whitman Birthplace Association 2004 Poet-in-Residence Samuel Menashe, and Walt Whitman Birthplace Association 1996 Poet-in-Residence Diane Wakowski. More events and further information is available at the Birthplace Association's website, www.waltwhitman.org.

The University of Paris VII will hold a two-day international conference (July 4-5, 2005), "Celebrating Walt Whitman," organized by Éric Athenot of the University of Tours and Mark Niemeyer of the University of Paris IV (Sorbonne). The aim of the conference is to assess the special significance of the original edition in the context of antebellum American belles-lettres and culture while evaluating its remarkable position in the series of editions that were to culminate in the definitive Leaves of Grass. The conference will also explore the continuing presence of the poetry and the figure of its creator in the works of writers of the two following centuries. Whitman as a cultural icon (in film, music, and art) will also be considered. Finally, a special emphasis will be placed on Whitman in France, how Leaves of Grass was first received in this country, what made it so important to French poets and poetry-lovers but also what the French practice of textual analysis (explication de texte) can contribute to Whitmanian studies through close readings of some of the poems. Further information is available from Éric Athenot (eric64@club-internet.fr) or Mark Niemeyer (Mark.Niemeyer@paris4.sorbonne.fr).

Karen Karbiener of NewYork University is developing an exhibit entitled "Walt Whitman and the Promise of Democracy, 1855-2005," scheduled to open at the South Street Seaport Museum in Manhattan on July 4, 2005, and run through December 2005. The exhibit, in the Schermerhorn Row Galleries, will provide a three-dimensional, multimedia introduction to Whitman's work and his vision of America's potential. Focal themes include sexuality and repression, spiritual options to organized religion, and Whitman's bohemian circle in New York City. Karbiener says she is "working on making the participants' experience active, participatory, and 'sensual." The Seaport is also working in conjunction with several institutions (such as the Museum of the City of New York, the Whitman Birthplace, and Columbia University) to schedule events relating to the $150^{\text {th }}$ anniversary of Leaves of Grass, including the Annual Marathon Reading of "Song of Myself," to take place in late May. Potential readers 
should check the Seaport website (www.southstseaport.org) to sign up for sections. Among other planned events is the production of a limited edition, letterpress "Song of Myself," to be published at Bowne \& Co., the nineteenthcentury job printing shop at the Seaport. The idea is to have the public help typeset the entire poem, making it perhaps the most democratic version of the poem yet available. Those interested in participating in these events, or those with suggestions for further events, should e-mail Karbiener at kk55@nyu.edu.

"Walt Whitman's Leaves of Grass: The Sesquicentennial Symposium" will be held at The College of New Jersey September 22-24, 2005. The College of New Jersey is celebrating its own Sesquicentennial in 2005, and this conference on the $150^{\text {th }}$ anniversary of the first edition of Leaves of Grass will be the academic centerpiece of the College's yearlong celebration. Sixteen of the nation's leading scholars and poets will address the symposium. Presentations will be divided into three broad strands: Whitman in the nineteenth century, Whitman in the twentieth century, and Whitman in the twenty-first century. More information is available from the conference organizers, Michael Robertson (mroberts@tcnj.edu) and David Blake (blake@tcnj.edu).

"The Making of Leaves of Grass," an exhibit and symposium celebrating Whitman as a bookmaker, will be held at The University of Iowa from November 2005 through January 2006. The symposium will take place on the weekend of November 11-13, 2005, and will examine the implications of Whitman's love of the book as material object. It is arguable that Whitman in fact did not think of his works as "texts" but rather as "books," each physical book having an existence and a meaning distinct from the others. So he tended to think of his various editions of Leaves not as a single evolving text, but as six separate books, each with its own history, its own social and political context, and its own cultural work to accomplish. The symposium will address the important relationship of those contexts to the physical changes in the various editions and the material identity that each book carries in its unique binding, page layout, decorations, and typeface. The exhibit, to be held at The University of Iowa Museum of Art, will focus on the making of Whitman's books and will feature editions of his work from 1855 to the present, with an emphasis on editions that demonstrate printing and design innovations. Books featured in the exhibit are from the University of Iowa Special Collections and from Kendall Reed's private collection. Keynote speaker will be Ezra Greenspan of Southern Methodist University. Directed by Ed Folsom and David Schoonover, this event hopes to draw those interested in Whitman and, more generally, those interested in the history of the book and the book arts. 
